\title{
The compliance evolution of the corporate governance codes in emerging European countries - a content analysis perspective
}

\author{
Pompei Mititean ${ }^{1, a}$

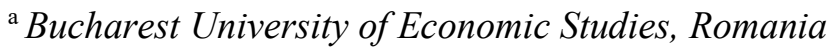

\begin{abstract}
Research Question: Does the corporate governance codes from 18 Emerging European countries respect the European Commission recommendations?
\end{abstract}

Motivation: The corporate governance is a wildly debated topic in the literature but only few studies are addressed to the level of compliance between the corporate governance and the European Commission recommendations, especially in emerging countries.

Idea: The objective of this study is to analyse the corporate governance codes form eighteen Emerging European Countries and examine if these countries comply with the recommendations of European Commission regarding corporate governance by using the content analysis technique. The main research proposition is to identify how many out of the 32 recommendations included in this analysis are fulfilled by the corporate governance codes from the Emerging European Countries and how these developed during time.

Data: Data sample consists of 18 corporate governance codes from Emerging European Countries, which are examined in the context of the recommendations of European Commission COM-284, and the next years updates from 2004 (2004/913/EC), 2005 (2005/162/EC) and 2009 (2009/384 and 385/EC), divided into five group, covering 32 recommendations.

Tools: The latest versions of corporate governance codes from each country, from 20042020, were downloaded, collecting the data manually from each corporate governance code using the content analysis technique.

Findings: The results illustrate that Slovenia and Czech Republic are the countries with the highest compliance degree, while Poland and Estonia are the countries with the least fulfilled recommendations

Contribution: This paper provides a general overview regarding the level of compliance of the corporate governance codes and European Commission recommendations, thus being a

${ }^{1}$ Corresponding author: Accounting Doctoral School, Bucharest University of Economic Studies; Piața Romană, 6, room 1117; email address: mititeanpompei19@stud.ase.ro 
starting point for researchers who will further study this subject. Secondly, we have contribute to the limited studies that analysed the evolution of corporate governance codes following the best practices for the companies issued by European Commission.

Keywords: corporate governance, corporate governance codes, Emerging European Countries.

\section{JEL codes: M41, G34}

\section{Introduction}

Over the past twenty years, the study of corporate governance in Emerging countries has becoming an important field of research (Ararat et al., 2020; Esqueda and O'Connor, 2019; Owusu, 2016; Yusof, 2016; Al-Malkawi et al., 2014; Peters et al., 2011, Siddiqui, 2009, Allen, 2005) increasing at international level. Based on these studies, the authors tried to provide an overview of the corporate governance in the emerging countries with the purpose to identify the mains gaps in literature. Starting with the Cadbury Report issued in the United Kingdom in 1992 by, at national level, the European countries tried to establish corporate codes of good practice governance being sustained by the European Commission with a set of recommendations that the countries should apply.

Despite the numerous research papers published on the topic of corporate governance codes in countries, a limited number of articles tried to make on overview regarding the European Commission recommendations with the corporate governance codes issued by the countries such as Kubicek et al. (2016), Hermes et al. (2007) and Hermes et al. (2006).

The purpose of this study is to compile the corporate governance codes from eighteen Eastern European Countries with the European Commission recommendations COM-284 published in 2004 and the following recommendation published in the next years regarding the position of the non-executive and supervisory directors and the committees under the board and the remuneration policy.

Considering the corpus literature studied, this paper approaches one main research question, relative to the corporate governance and European Commission recommendations:

RQ. Does the corporate governance codes from eighteen Emerging European countries respect the European Commission recommendations?

By using the content analysis technique, the key characteristics of the results of this study are presented by comparing the results of this study with the results of Kubicek 
et al. (2016), Hermes et al. (2006) and Hermes et al. (2007). The results of this research provide a general overview regarding the compilation between the national corporate codes from eighteen Emerging European Countries with the latest European Commission recommendations.

Future research directions may attempt to broaden the sample to the all-European countries who published a corporate governance code and to find new possible patterns of the research in Europe. Moreover, future research could also investigate if the European Commission recommendations were implemented into the company's annual reports.

This paper is organized as follows: Section 2 includes an overview of the corporate governance codes studies, offering an international background. In Section 3, the key research design is explained, while in Section 4 the research findings are discussed. Section 5 is dedicated to the concluding remarks of this study.

\section{Literature review and hypotheses development}

Both the corporate governance of European countries and their systems are different from one country to another (Kubicek et al., 2016). The big failures of the United Kingdom companies such as Polly Pek, P\&G, BCCI and Maxyell led to identifying the need for using good practices in corporate governance. Thus, in 1992 the Cadbury Report was published. This report was addressed to the listed companies and it contains a code of good practice. Since then, the report has become a benchmark for the use of best practices in corporate governance in the European countries.

According to Aguilera and Curevo-Cazurra (2004) these codes are seen as a set of good practices in the behaviour and structure of a company's management having the role of reducing the deficiencies in the corporate governance system. By studying the corporate governance in emerging markets, Ararat et al. (2020) shows how the corporate governance reforms have been reinforcing in emerging markets. The authors results illustrate that the corporate governance is a key factor of development, leading the research in this area, focusing on the ownership structures, property rights and organisational forms.

In their study, Bosáková et al. (2019) analysed and compared eleven corporate governance codes from emerging and developed countries to see if these countries follow the best practices. They found out that the „comply or explain” approach is insufficient for following the best practices, especially for the emerging economics and the countries adopted a stricter approach for the compliance of the national codes with company characteristics. 
An interesting study conducted by Cicon et al. (2010) analyses the codes from 23 European Countries from various points of view. Using a Latent Systematic Analysis technique, they obtained some interesting results regarding the thematic content, variability, and convergence. The authors decomposed the codes into five themes, with substantial cross-sectional variability in their relative importance. The authors discovered that a very important aspect in explaining the theme of a code and change of the content is owned by the issuer of the code (e.g., government versus stock exchange). The codes are different depending on the rules from each country. However, they have a common law, which is the starting point in their development. Cuomo et al. (2016) in their study, published in Corporate Governance: An International Review, studied the recent trends and tried to indicate the future types of research in the domain of corporate governance codes. According to the authors, the corporate governance codes can be split on three levels: international (e.g., OECD), national (e.g., Stock exchange) and the individual firm. Their study explains how the codes changed over time and how the institutional actors play their role.

Hugill and Siegel (2012) conducted an interesting study regarding to the quality of the corporate governance from emerging countries focusing on who determine the quality of it. Using a panel data the authors found out that in emerging countries the firms are at the same level with the countries in explaining the quality of corporate governance. This mean that the companies has the ability to increase the quality of corporate governance from emerging countries. Feng et al. (2017) studied the association between national culture and the best practices in emerging economies and provides that the national culture influence the best practices in corporate governance.

Esqueda and O'Connor (2019) examined the impact of the firm life cycle on corporate governance in emerging markets. By using the regression analysis, the results illustrate that a good predictor of corporate governance is the listing level decision instead of firm life cycle. By having a stringent regulation, the firms show improvements in corporate governance by choosing the quality of corporate governance considering their individual needs. Owusu (2016) investigated the determinants of a good corporate governance in an emerging country from Africa by using a panel data analytical framework. The analysis was based on a sample of 35 firms from Ghana Stock Exchange (GSE) by collecting data from their annual reports from 2000 to 2009. The author identified that there is a positive and statistically significant relationship between three determinants: external financing needs, firm size, institutional shareholdings and governance quality being measured by the Ghanaian corporate governance index.

Another interesting study was made by Al-Malkawi et al. (2014) who analysed the corporate governance practices in emerging markets by developing an un-weighted Corporate Governance Index (CGI) model for non-financial firms in the Gulf Cooperation Council's oil rich countries. The authors results illustrate that $69 \%$ of 
the companies approach the attributes issued in CGI and the listed companies have the best adherence. Peters et al. (2011) comparing the practices of corporate governance and corporate social responsibility from mature markets with the practices from emerging markets concluded that the global corporate governance and corporate social responsibility system can be implemented in emerging markets being based on western codes.

Ferdous et al. (2014) studied the corporate governance from Bangladesh comparing their results with the corporate governance from India and Pakistan, all of these being emerging countries. They focused on three main topics regarding to the compliance with international recommendations, the variation between them and how these items are treated in the national codes. The results shows that the corporate governance codes should be updated to respect the best practices and an important role to ensure the best practices are provided by the enforcement mechanism and the issuer of the governance code.

Sahin (2014) investigate how the corporate governance codes are legitimated in emerging and developed countries. By collecting the data for 58 countries and using the regression model the author found out that the legitimation follows a different path in emerging and developed countries, and the countries based on common law more likely to develop their best practices in corporate governance.

Hermes et al. (2006) published an interesting study regarding the corporate governance codes in European Union and they tried to show if external or domestic forces drive the codes. By comparing the codes content with the European Commission priorities, the authors showed that the majority of the European codes does not respect the European Commission priorities, concluding that the codes may be driven by external and domestic forces. Hermes et al. (2007) identified the proportion in which the corporate governance codes of the European Union countries are driven by internal or external forces and if the codes are in accordance with the recommendations of European Commission. The authors focused on three main areas: disclosure rules, strengthening shareholders rights and modernising boards. The results show that only around $50 \%$ of the recommendations of the European Commission are respected by the codes from Eastern European countries and that the content of the codes is driven by domestic forces.

Similarly with Hermes et al. (2006) and Hermes et al. (2007), Kubeiceck et al. (2016) analysed the corporate governance codes for the European Union states member and examined if European Union shapes the countries codes. Based on the study of diffusion, the authors considered how the form of exogenous and endogenous forces contains the codes of corporate governance in the member countries of the European Union, following the recommendations of the European Commission on corporate governance published in 2003 (COM-284). The authors have not been able to prove if the national corporate governance codes are influenced 
directly by the European Commissioning recommendation. They considered that exogenous forces shape the content of corporate governance codes.

Bosakova et al. (2019) analysed and compared the content of the corporate governance codes from 11 developing and emerging developing and emerging countries to see if they complied with the OECD principle of corporate governance, which are considered as being the best practices in corporate governance. The results showed that the investigated countries have issued well-developed codes, comparable with the codes from developed countries, which also contributed to the development of many areas, proving that these countries adopted the „complain and explain" principle.

Regarding corporate governance in emerging countries, Claessens and Yurtoglu (2013) made a study that reviews the recent research on corporate governance and traces the dimensions in the manner of functioning in firms from emerging countries. The authors' results showed that a good corporate governance increases the efficiency and the return on equity at firm level.

In their study, Albu and Girbina (2015) studied the attitude of Romanian companies regarding to the comply or explain principle. The authors analysed 67 non-financial companies listed on the BVB in 2010 and 2011, by using a combination of five index to measure the compliance of corporate governance. The results reveal that are some difficulties in the application of the principle because of the applicable laws and regulations because Romania has already a low enforcement of the principles.

Boitan and Maruszewska (2021) studied the differences and the similarities of the corporate governance in European Union. By conducting an exploratory analysis, using the taxonomy analysis on 29 European countries for 2019 year. The results shows that the European Union countries adapt their corporate governance practices depending on the technique, culture and political process. Also the results suggest that some countries such as Estonia, Germany, Czech Republic, Belgium, Malta, Austria, France, Finland, Netherlands, Latvia, Lithuania, Cyprus, Poland, Romania, Italy and Portugal can develop their best practices using the experience of other countries that found particular institutional features of corporate governance.

Shala and Qehaja (2021) studied and compared the practices and corporate governance frameworks from nine South-Eastern European countries to see if the these countries made some progress or not regarding this subject by using the comparative analysis. By taking in account the corporate governance practices and law in banks system the results shows that Albania has a lowest score because they didn't implemented the voluntary corporate governance codes meanwhile Republic of Croatia and Slovenia has the highest scores on corporate governance practices by having an excellent addition to the legislation. 


\section{Research methodology}

This paper analyses the content of the corporate governance codes form eighteen Emerging Eastern European Countries (Bulgaria, Croatia, Czech Republic, Hungary, Poland, Romania, Serbia, Slovakia, Slovenia, Ukraine, Albania, Bosnia \& Herzegovina Estonia, Latvia, Lithuania, Macedonia Montenegro and Turkey) and the recommendation issued by European Commission using the content analysis technique. During the analysed period, these countries issued one or more corporate governance codes, as presented in Table 1.

Table 1. Corporate Governance Codes in Emerging countries

\begin{tabular}{|c|c|c|c|c|c|}
\hline Country & $\begin{array}{c}\text { EU } \\
\text { Membe } \\
\text { rs }\end{array}$ & $\begin{array}{l}\text { No. Of } \\
\text { codes }\end{array}$ & $\begin{array}{c}\text { First } \\
\text { version }\end{array}$ & $\begin{array}{c}\text { Last } \\
\text { version }\end{array}$ & Year of issued \\
\hline Bulgaria & YES & 2 & 2007 & 2012 & 2007, 2012 \\
\hline $\begin{array}{l}\text { Croatia } \\
\text { Czech }\end{array}$ & YES & 2 & 2008 & 2009 & 2008,2009 \\
\hline Republic & YES & 2 & 2001 & 2004 & 2001,2004 \\
\hline Hungay & YES & 4 & 2002 & 2011 & $\begin{array}{c}2002,2007,2008 \text { and } 2018 \\
2002,2002,2004,2007,\end{array}$ \\
\hline Poland & YES & 7 & 2002 & 2015 & $2010,2012,2015$ \\
\hline Romania & YES & 3 & 2000 & 2015 & 2000,2009 and 2015 \\
\hline Serbia & NO & 1 & 2008 & 2008 & 2008 \\
\hline Slovakia & NO & 2 & 2002 & 2007 & $\begin{array}{c}2002,2007 \\
2004,2005,2007,2009\end{array}$ \\
\hline Slovenia & NO & 7 & 2004 & 2018 & 2016, 2016 and 2018 \\
\hline Ukraine & NO & 4 & 2003 & 2020 & $2003,2018,2020$ and 2021 \\
\hline Albania & YES & 1 & 2008 & 2008 & 2008 \\
\hline $\begin{array}{l}\text { Bosnia \& } \\
\text { Herzegovina }\end{array}$ & NO & 3 & 2006 & 2011 & 2006,2009 and 2011 \\
\hline Estonia & YES & 1 & 2006 & 2006 & 2006 \\
\hline Latvia, & YES & 3 & 2005 & 2020 & 2005,2010 and 2020 \\
\hline Lithuania, & YES & 3 & 2003 & 2019 & 2003, 2010 and 2019 \\
\hline Macedonia & NO & 2 & 2003 & 2006 & 2003 and 2006 \\
\hline Montenegro & NO & 1 & 2009 & 2009 & 2009 \\
\hline Turkey & NO & 3 & 2003 & 2014 & 2003,2005 and 2014 \\
\hline
\end{tabular}

(Source: ECGI webpage, consulted July 2021, https://ecgi.global/content/codes)

The aim of the study is to compile the recommendations of European Commission with the latest version of the corporate governance codes of eighteen European emerging countries. Firstly, we compile the list of recommendation published in 
2003 (2003/284/EC), 2004 (2004/913/EC), 2005 (2005/162/EC) and 2009 (2009/384 and 385/EC) by the European Commission and the recommendation published in the next years related to the remuneration policy and the role of nonexecutive and supervisory board. Following the steps made by Hermes et al. (2006), Hermes et al. (2007) and Kubicek (2016) we divide the recommendations into 32 priorities. These recommendations are divided into five groups:

- Enhancing Corporate Governance disclosure and institutional investors (recommendation 1-9);

- Strengthening shareholders' rights (recommendation 10-12);

- Modernising the board of directors (recommendation 13-18);

- Remuneration policy of general and individual directors (recommendation 19-24);

- Role of non-executive or supervisory directors of listed companies (recommendation 25-32).

Data sample consists of 18 corporate governance codes from Emerging European Countries, which are examined in the context of the recommendations of European Commission COM-284, and the next years updates from 2004 (2004/913/EC), 2005 (2005/162/EC) and 2009 (2009/384 and 385/EC), divided into five group, covering 32 recommendations.

The first step into this analysis is to download the latest versions of corporate governance codes from each country, from 2004-2020, collecting the data manually from each corporate governance code using the content analysis technique. The next step is to search for the recommendations in the content of the codes. Considering that the corporate governance codes are different from one country to another, we have decided to check the recommendations in a broad sense rather than exact wording. If the recommendations of the code comply with the ones of the European Commission, they are marked with „yes”, otherwise they are marked with „No". The average of the compliance and the percentages was calculated using the Microsoft Excel tool.

Table 2. Recommendation according to the European Commission

\begin{tabular}{lll}
\hline No & \multicolumn{1}{c}{ Recommendation } & According to \\
\hline 1 & $\begin{array}{l}\text { The operation of the shareholder meeting and its key powers; } \\
2\end{array}$ & $\begin{array}{l}\text { The description of shareholder rights and how they can be } \\
\text { exercised; }\end{array}$ \\
3 & $\begin{array}{l}\text { The composition and operation of the board and its committees; } \\
4\end{array}$ & $\begin{array}{l}\text { The shareholders holding major holdings, and their voting and } \\
\text { control rights as well as key agreements; }\end{array}$ \\
5 & $\begin{array}{l}\text { The other direct and indirect relationships between these major } \\
\text { shareholders and the company; }\end{array}$ \\
6 & The existence and nature of a risk management system; \\
\hline
\end{tabular}




\begin{tabular}{|c|c|c|}
\hline No & Recommendation & According to \\
\hline 7 & $\begin{array}{l}\text { A reference to a code on corporate governance, designated for } \\
\text { use at national level, with which the company complies or in } \\
\text { relation to which it explains deviations; }\end{array}$ & \\
\hline 8 & $\begin{array}{l}\text { A disclosure of investment policy with respect to the exercise of } \\
\text { voting rights in companies in which they invest; }\end{array}$ & \\
\hline 9 & $\begin{array}{l}\text { Disclosure to their beneficial holders at their request how these } \\
\text { rights have been used in a particular case. }\end{array}$ & \\
\hline 10 & Access the relevant information before the General Meetings; & \\
\hline 11 & Shareholder democracy: the one share-one vote principle; & \\
\hline 12 & Provisions for cross-border voting; & \\
\hline 13 & $\begin{array}{l}\text { In areas of possible conflicts of interest, decisions should be } \\
\text { made by non-executive directors; }\end{array}$ & \\
\hline 14 & Disclosure of the remuneration policy; & \\
\hline 15 & Disclosure of details of remuneration of individual directors; & \\
\hline 16 & $\begin{array}{l}\text { Prior approval by the shareholder meeting of share and share } \\
\text { option schemes for directors; }\end{array}$ & \\
\hline 17 & $\begin{array}{l}\text { Proper recognition in the annual accounts of the costs of such } \\
\text { schemes for the company; }\end{array}$ & \\
\hline 18 & Collective responsibility of all board members. & \\
\hline 19 & $\begin{array}{l}\text { If the remuneration policy includes variable components of } \\
\text { remuneration, company should set limits on the variable } \\
\text { components; }\end{array}$ & \multirow{6}{*}{$\begin{array}{l}2004 / 913 / \mathrm{EC} \\
\text { and } 2009 / 384 \\
\text { and } 385 / \mathrm{EC}\end{array}$} \\
\hline 20 & $\begin{array}{l}\text { Award of variable components of remuneration should be } \\
\text { subject to predetermined and measurable performance criteria. }\end{array}$ & \\
\hline 21 & $\begin{array}{l}\text { The remuneration policy and any significant change should be } \\
\text { an explicit item on the agenda of the annual general meeting and } \\
\text { submitted to the general meeting for a vote; }\end{array}$ & \\
\hline 22 & $\begin{array}{l}\text { Total remuneration and other benefits (i.e., shares and/or rights } \\
\text { to acquire share, pension schemes) granted to individual } \\
\text { directors should be disclosed in detail in the annual accounts; }\end{array}$ & \\
\hline 23 & Shares should not vest for at least three years after their award; & \\
\hline 24 & $\begin{array}{l}\text { Remuneration of non-executive or supervisory directors should } \\
\text { not include share options. }\end{array}$ & \\
\hline 25 & $\begin{array}{l}\text { The present or past executive responsibilities of the board's } \\
\text { chairman should not stand in the way of his ability to exercise } \\
\text { objective supervision; }\end{array}$ & \multirow{4}{*}{$2005 / 162 / \mathrm{EC}$} \\
\hline 26 & $\begin{array}{l}\text { A sufficient number of independent non-executive or } \\
\text { supervisory directors should be elected to the board to ensure } \\
\text { that any conflict of interest involving directors will be properly } \\
\text { dealt with; }\end{array}$ & \\
\hline 27 & $\begin{array}{l}\text { Description of the nomination, remuneration and audit } \\
\text { committees should make recommendations aimed at preparing } \\
\text { the decisions to be taken by the board itself; }\end{array}$ & \\
\hline 28 & $\begin{array}{l}\text { At least one of the members of the remuneration committee } \\
\text { should have knowledge of and experience in the field of } \\
\text { remuneration; }\end{array}$ & \\
\hline
\end{tabular}


The compliance evolution of the corporate governance codes in emerging European countries - a content analysis perspective

\begin{tabular}{lll}
\hline No & \multicolumn{1}{c}{ Recommendation } & According to \\
\hline 29 & $\begin{array}{l}\text { Companies may group the functions as they see fit and if } \\
\text { necessary, create fewer than three committees: } \\
\text { The board should make public at least once year information } \\
\text { about its internal organisation and ensure that shareholders are } \\
\text { properly informed as regards the affairs of the company, its } \\
\text { strategic approach, and the management of risks and conflicts of } \\
\text { interest; }\end{array}$ \\
31 & $\begin{array}{l}\text { The code should describe appointment and removal of non- } \\
\text { executive or supervisory directors; } \\
32\end{array}$ \\
$\begin{array}{l}\text { The provides profile of non-executive or supervisory director in } \\
\text { terms of their qualifications, commitment, and independence. }\end{array}$ & \\
\hline
\end{tabular}
(Source: Kubicek 2016: 327-328-331-332)

The first 18 recommendations were published in 2003 by the European Commission under the name COM-284, which contain recommendations regarding the first three groups. The group of remuneration policy of general and individual directors contain the recommendations 19-24, updated in 2004 (2004/913/EC) and 2005 (2005/162/EC). The last group is covered by the recommendations issued by the documents from 2009 (2009/384 and 385/EC). All recommendations are provided in Table 2.

\section{Results}

The figure bellow presents the number of European countries who adopted a code of best practices in corporate Governance. According to the figure below, during 1992 and 1999, a total number of 9 countries adopted a code of corporate governance. Stating with the 2000s the number of European countries who adopted a corporate governance code increased and by the end of 2010, it reached a number of 44 countries out of 51 European countries.

In 2002, a total number of 7 countries, Austria, Cyprus, Switzerland, Poland, Russia, Slovakia and Hungary, adopted a code of corporate governance. The last two European countries who adopted a corporate governance code were Armenia and Azerbaijan. Regarding the Eastern European countries who adopted for the first time a corporate governance code, Romania was the first one who had the initiative to publish its first code in 2000, being followed by Czech Republic in 2001, Macedonia and Ukraine in 2003. 


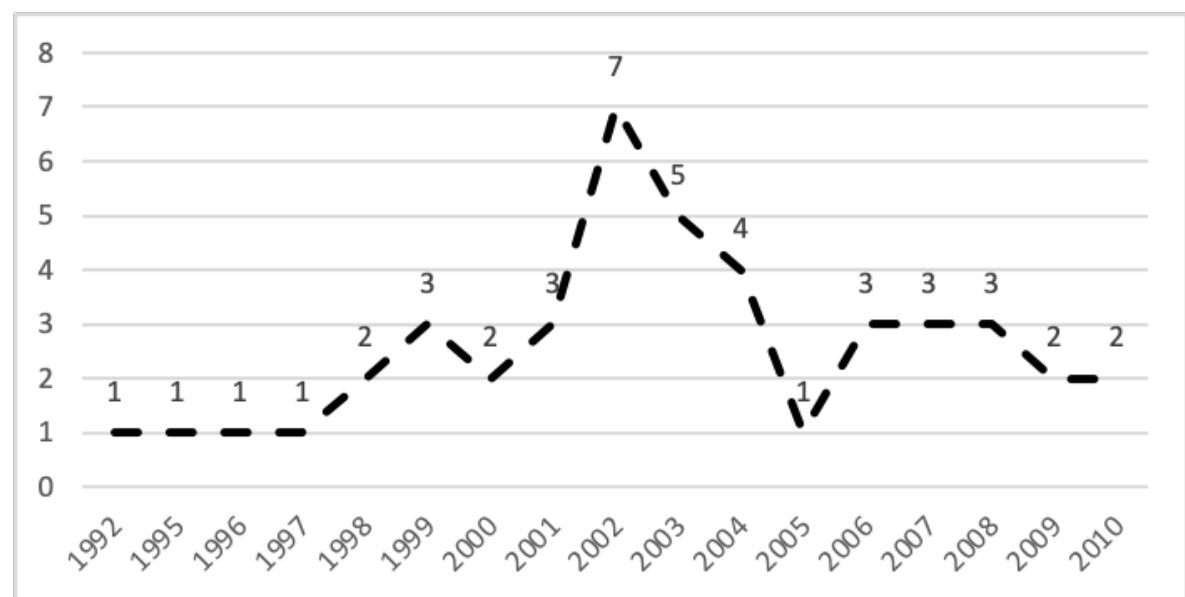

Figure 1. Evolution in Time of the New Codes in Europe

(Source: ECGI webpage, consulted March 2021, https://ecgi.global/content/codes)

The top five countries with the most revisions of the codes were presented above. United Kingdom published the first corporate governance code in 1992 and starting with this year until the end of 2020 the code was reviewed 55 times. On the second place is Germany with 21 reviews, followed by France, Spain and The Netherland on the third, fourth and fifth place with less than 20 reviews.

Table 3. Top Five Countries with Most Revisions of the Corporate Governance Codes

\begin{tabular}{lccc}
\hline Country & First Publication & Last review & Total reviews \\
\hline United Kingdom & 1992 & 2020 & 55 \\
Germany & 1998 & 2019 & 21 \\
France & 1995 & 2020 & 19 \\
Spain & 1996 & 2020 & 17 \\
Netherlands & 1997 & 2018 & 13 \\
\hline
\end{tabular}

(Source: ECGI webpage, consulted March 2021, https://ecgi.global/content/codes)

Table 4. Enhancing Corporate Governance disclosure and institutional investors

\begin{tabular}{|c|c|c|c|c|c|c|c|c|c|c|c|}
\hline $\begin{array}{l}\text { Recommendations } \\
\text { Countries }\end{array}$ & 1 & 2 & 3 & 4 & 5 & 6 & 7 & 8 & 9 & $\begin{array}{c}\text { No of } \\
\text { compli } \\
\text { ance }\end{array}$ & $\begin{array}{c}\text { \%o of } \\
\text { compli } \\
\text { ance } \\
\end{array}$ \\
\hline \multirow{3}{*}{ Bulgaria } & $\mathrm{Y}$ & $\mathrm{Y}$ & $\mathrm{Y}$ & $\mathrm{N}$ & $\mathrm{N}$ & $\mathrm{Y}$ & $\mathrm{Y}$ & $\mathrm{N}$ & $\mathrm{N}$ & \multirow{3}{*}{5 of 9} & \multirow{3}{*}{$56 \%$} \\
\hline & es & es & es & o & o & es & es & o & o & & \\
\hline & $\mathrm{Y}$ & $\mathrm{Y}$ & $\mathrm{Y}$ & $\mathrm{N}$ & $\mathrm{N}$ & Y & $\mathrm{N}$ & $\mathrm{N}$ & $\mathrm{N}$ & & \\
\hline \multirow[t]{2}{*}{ Croatia } & es & es & es & o & o & es & o & o & o & \multirow[t]{2}{*}{4 of 9} & \multirow[t]{2}{*}{$44 \%$} \\
\hline & $\mathrm{Y}$ & $\mathrm{Y}$ & $\mathrm{Y}$ & $\mathrm{Y}$ & $\mathrm{Y}$ & $\mathrm{Y}$ & $\mathrm{Y}$ & $\mathrm{Y}$ & $\mathrm{Y}$ & & \\
\hline \multirow[t]{2}{*}{ Czech Republic } & es & es & es & es & es & es & es & es & es & \multirow[t]{2}{*}{9 of 9} & \multirow[t]{2}{*}{$100 \%$} \\
\hline & $\mathrm{Y}$ & $\mathrm{Y}$ & $\mathrm{Y}$ & $\mathrm{N}$ & $\mathrm{N}$ & $\mathrm{Y}$ & $\mathrm{Y}$ & $\mathrm{N}$ & $\mathrm{N}$ & & \\
\hline Hungary & es & es & es & $\mathrm{o}$ & $\mathrm{o}$ & es & es & $\mathrm{O}$ & $\mathrm{o}$ & 5 of 9 & $56 \%$ \\
\hline
\end{tabular}


The compliance evolution of the corporate governance codes in emerging European countries - a content analysis perspective

\begin{tabular}{|c|c|c|c|c|c|c|c|c|c|c|c|}
\hline $\begin{array}{l}\text { Recommendations } \\
\text { Countries }\end{array}$ & 1 & 2 & 3 & 4 & 5 & 6 & 7 & 8 & 9 & $\begin{array}{c}\text { No of } \\
\text { compli } \\
\text { ance }\end{array}$ & $\begin{array}{c}\text { \% of } \\
\text { compli } \\
\text { ance }\end{array}$ \\
\hline \multirow{3}{*}{ Poland } & $\mathrm{Y}$ & $\mathrm{Y}$ & $\mathrm{Y}$ & $\mathrm{N}$ & $\mathrm{Y}$ & $\mathrm{Y}$ & $\mathrm{Y}$ & $\mathrm{N}$ & $\mathrm{N}$ & \multirow{3}{*}{6 of 9} & \multirow{3}{*}{$67 \%$} \\
\hline & es & es & es & o & es & es & es & o & o & & \\
\hline & $\mathrm{Y}$ & $\mathrm{Y}$ & Y & $\mathrm{N}$ & $\mathrm{Y}$ & $\mathrm{Y}$ & $\mathrm{Y}$ & $\mathrm{N}$ & $\mathrm{N}$ & & \\
\hline \multirow[t]{2}{*}{ Romania } & es & es & es & o & es & es & es & o & o & \multirow[t]{2}{*}{6 of 9} & \multirow[t]{2}{*}{$67 \%$} \\
\hline & $\mathrm{Y}$ & $\mathrm{Y}$ & Y & $\mathrm{N}$ & $\mathrm{N}$ & $\mathrm{Y}$ & $\mathrm{Y}$ & $\mathrm{Y}$ & $\mathrm{N}$ & & \\
\hline \multirow[t]{2}{*}{ Serbia } & es & es & es & o & o & es & es & es & o & \multirow[t]{2}{*}{6 of 9} & \multirow[t]{2}{*}{$67 \%$} \\
\hline & $\mathrm{Y}$ & $\mathrm{Y}$ & $\mathrm{Y}$ & $\mathrm{Y}$ & $\mathrm{Y}$ & $\mathrm{Y}$ & $\mathrm{Y}$ & $\mathrm{Y}$ & $\mathrm{Y}$ & & \\
\hline \multirow[t]{2}{*}{ Slovakia } & es & es & es & es & es & es & es & es & es & \multirow[t]{2}{*}{9 of 9} & \multirow[t]{2}{*}{$100 \%$} \\
\hline & $\mathrm{Y}$ & $\mathrm{Y}$ & $\mathrm{Y}$ & $\mathrm{Y}$ & $\mathrm{Y}$ & $\mathrm{Y}$ & $\mathrm{Y}$ & $\mathrm{Y}$ & $\mathrm{Y}$ & & \\
\hline \multirow[t]{2}{*}{ Slovenia } & es & es & es & es & es & es & es & es & es & \multirow[t]{2}{*}{9 of 9} & \multirow[t]{2}{*}{$100 \%$} \\
\hline & $\mathrm{Y}$ & $\mathrm{Y}$ & $\mathrm{Y}$ & $\mathrm{N}$ & $\mathrm{Y}$ & $\mathrm{Y}$ & $\mathrm{Y}$ & $\mathrm{N}$ & $\mathrm{N}$ & & \\
\hline Ukraine & es & es & es & $\mathrm{o}$ & es & es & es & o & o & 6 of 9 & $67 \%$ \\
\hline \multirow{2}{*}{ Albania } & $\mathrm{Y}$ & $\mathrm{N}$ & $\mathrm{Y}$ & $\mathrm{N}$ & $\mathrm{N}$ & $\mathrm{Y}$ & $\mathrm{Y}$ & $\mathrm{N}$ & $\mathrm{N}$ & \multirow{2}{*}{4 of 9} & \multirow{2}{*}{$44 \%$} \\
\hline & es & o & es & o & o & es & es & o & o & & \\
\hline \multirow{2}{*}{$\begin{array}{l}\text { Bosnia \& } \\
\text { Herzegovina }\end{array}$} & $\mathrm{Y}$ & $\mathrm{Y}$ & $\mathrm{Y}$ & $\mathrm{N}$ & $\mathrm{Y}$ & $\mathrm{Y}$ & $\mathrm{N}$ & $\mathrm{N}$ & $\mathrm{Y}$ & \multirow{2}{*}{6 of 9} & \multirow{2}{*}{$67 \%$} \\
\hline & es & es & es & o & es & es & $\mathrm{o}$ & o & es & & \\
\hline \multirow{2}{*}{ Estonia } & $\mathrm{Y}$ & $\mathrm{Y}$ & $\mathrm{Y}$ & $\mathrm{N}$ & $\mathrm{N}$ & $\mathrm{Y}$ & $\mathrm{N}$ & $\mathrm{N}$ & $\mathrm{Y}$ & \multirow{2}{*}{5 of 9} & \multirow{2}{*}{$56 \%$} \\
\hline & es & es & es & o & $\mathrm{o}$ & es & $\mathrm{o}$ & o & es & & \\
\hline \multirow{2}{*}{ Latvia } & $\mathrm{Y}$ & $\mathrm{N}$ & $\mathrm{N}$ & $\mathrm{Y}$ & $\mathrm{Y}$ & $\mathrm{Y}$ & $\mathrm{N}$ & $\mathrm{N}$ & $\mathrm{N}$ & \multirow{2}{*}{4 of 9} & \multirow{2}{*}{$44 \%$} \\
\hline & es & o & o & es & es & es & $\mathrm{o}$ & $\mathrm{o}$ & o & & \\
\hline \multirow{2}{*}{ Lithuania } & $\mathrm{Y}$ & $\mathrm{N}$ & $\mathrm{N}$ & $\mathrm{Y}$ & $\mathrm{Y}$ & $\mathrm{Y}$ & $\mathrm{Y}$ & $\mathrm{N}$ & $\mathrm{Y}$ & 6 of 9 & $67 \%$ \\
\hline & es & o & o & es & es & es & es & o & es & & \\
\hline Macedonia & $\mathrm{Y}$ & $\mathrm{Y}$ & $\mathrm{Y}$ & $\mathrm{N}$ & $\mathrm{Y}$ & $\mathrm{Y}$ & $\mathrm{Y}$ & $\mathrm{N}$ & $\mathrm{Y}$ & 7 of 9 & $78 \%$ \\
\hline inacedonra & es & es & es & o & es & es & es & o & es & & \\
\hline Monteneoro & $\mathrm{Y}$ & $\mathrm{Y}$ & $\mathrm{Y}$ & $\mathrm{N}$ & $\mathrm{N}$ & $\mathrm{N}$ & $\mathrm{N}$ & $\mathrm{N}$ & $\mathrm{Y}$ & 4 of 9 & $44 \%$ \\
\hline iviontenegro & es & es & es & $\mathrm{o}$ & o & o & o & o & es & 4 OI 9 & $44 \%$ \\
\hline Turkey & $\mathrm{Y}$ & $\mathrm{N}$ & $\mathrm{Y}$ & $\mathrm{Y}$ & $\mathrm{Y}$ & $\mathrm{Y}$ & $\mathrm{N}$ & $\mathrm{Y}$ & $\mathrm{N}$ & 6 of 9 & $67 \%$ \\
\hline & es & $\mathrm{o}$ & es & es & es & es & $\mathrm{O}$ & es & $\mathrm{o}$ & & \\
\hline Codes including & 1 & 1 & 1 & & 1 & 1 & 1 & & 8 & Avera & $66 \%$ \\
\hline recommendation & 8 & 4 & 6 & 6 & 1 & 7 & 2 & 5 & 8 & ge & $66 \%$ \\
\hline
\end{tabular}

The compliance of the first nine recommendation with the corporate governance codes from our sample were presented in Table 4, describing the level of enhancing of the corporate governance disclosure and institutional investors. The level of compliance is more than $66 \%$, our results being similarly with the results of Kubicek et al. (2016), having a high level of compliance.

Comparing the results of Hermes et al. (2006) and Kubicek et al. (2016) it can be seen that there is a significant progress. In the prior research of Hermes et al. (2006), all the countries included in the study do not respect the recommendations of European Commission. In the Kubicek et al. (2016) study, 3 out of 9 recommendations $(1,3$ and 6$)$ are respected by all countries included into the study, meanwhile in this research it can be seen that only one recommendations are fully 
respected by all countries, referring to the operation of the shareholder meeting and its key powers. Recommendation regarding to the disclosure of investment policy with respect to the exercise of voting rights in companies in which they invest is the less respected recommendation, being respected only by 5 countries (Czech Republic, Serbia, Slovakia, Slovenia and Turkey) being followed by the fourth recommendation, which is respected only by 6 countries out of 18 , referring to the shareholders holding major holdings, and their voting and control rights as well as key agreements. Croatia, Latvia, Serbia and Montenegro are the countries who respect the less recommendations, regarding to this topic, by having a level of compliance of $44 \%$ out of $100 \%$, meanwhile countries such Czech Republic, Slovenia and Slovakia have a level of compliance of $100 \%$.

Table 5. Strengthening Shareholder's Rights and Modernising the Board of Directors

\begin{tabular}{|c|c|c|c|c|c|c|c|c|c|c|c|}
\hline $\begin{array}{l}\text { Recommendations } \\
\text { Countries } \\
\end{array}$ & 10 & 11 & 12 & 13 & 14 & 15 & 16 & 17 & 18 & $\begin{array}{c}\text { No of } \\
\text { compliance }\end{array}$ & $\begin{array}{c}\% \text { of } \\
\text { compliance }\end{array}$ \\
\hline Bulgaria & Yes & No & No & No & Yes & Yes & No & No & No & 3 of 9 & $33 \%$ \\
\hline Croatia & Yes & Yes & No & Yes & Yes & Yes & No & No & Yes & 6 of 9 & $67 \%$ \\
\hline Czech Republic & Yes & No & Yes & Yes & Yes & Yes & Yes & Yes & Yes & 8 of 9 & $89 \%$ \\
\hline Hungary & Yes & Yes & No & Yes & Yes & Yes & Yex & Yes & No & 7 of 9 & $78 \%$ \\
\hline Poland & Yes & No & No & Yes & Yes & Yes & No & No & No & 4 of 9 & $44 \%$ \\
\hline Romania & Yes & No & No & Yes & Yes & Yes & No & No & No & 4 of 9 & $44 \%$ \\
\hline Serbia & Yes & No & No & Yes & Yes & Yes & No & No & No & 4 of 9 & $44 \%$ \\
\hline Slovakia & Yes & No & Yes & Yes & Yes & Yes & Yes & No & Yes & 7 of 9 & $78 \%$ \\
\hline Slovenia & Yes & No & No & Yes & Yes & Yes & Yer & No & Yes & 6 of 9 & $67 \%$ \\
\hline Uhraine & Yes & Yes & No & Yes & Yes & Yes & Yex & No & Yes & 7 of 9 & $78 \%$ \\
\hline Albania & Yes & No & No & Yes & Yes & Yes & No & No & Yes & 5 of 9 & $56 \%$ \\
\hline Bognia \& Herzegovina & Yes & Yes & No & Yes & Yes & Yes & No & No & No & 5 of 9 & $56 \%$ \\
\hline Estonia & Yes & No & No & Yes & No & Yes & No & No & No & 3 of 9 & $33 \%$ \\
\hline Latvia & Yes & No & No & Yes & Yes & Yes & No & No & No & 4 of 9 & $44 \%$ \\
\hline Lithuania & Yes & No & No & Yes & Yes & Yes & Yes & No & Yes & 6 of 9 & $67 \%$ \\
\hline Macedonia & Yes & No & No & Yes & No & Yes & Yex & No & No & 4 of 9 & $44 \%$ \\
\hline Nontenegro & Yes & No & No & Yes & Yes & Yes & No & No & No & 4 of 9 & $44 \%$ \\
\hline Turkey & Yes & No & Yes & Yes & Yes & Yes & No & Yes & No & 6 of 9 & $67 \%$ \\
\hline $\begin{array}{l}\text { Codes inclnding } \\
\text { recommendation }\end{array}$ & 18 & 4 & 3 & 17 & 16 & 18 & 7 & 3 & 7 & Average & $\mathbf{5 7} \%$ \\
\hline
\end{tabular}

The compliance of the corporate governance codes with the recommendations of European Commission regarding to the strengthening shareholder's rights and modernising the board of directors are presented in Table 5. The results show that recommendations referring to the access the relevant information before the General Meetings (10) and to the disclosure of details of remuneration of individual directors (15) are respected by all countries, being included in their national codes, followed by the recommendation 13 referring to who should make the decisions in case of conflicts of interest. The less respected recommendations are the recommendation 
number 12 , related to the provisions for cross-border voting, and number 17 , related to the proper recognition in the annual accosts of the costs of such remuneration schemes for the company.

The average number of corporate codes who included the recommendations of the European Commission is $57 \%$, only 10 out of 18 countries codes respect more than 50 percent of the total recommendation. Czech Republic respects 8 out of the 9 recommendations issued by the European Commission regarding strengthening shareholder's rights and modernising the board of directors. Only the recommendation number 11, regarding shareholder democracy, referring to the oneshare-one vote principle, is not respected. The last position in terms of compliance with the recommendations of European Commission is Bulgaria and Estonia, which complies with only 3 of the 9 recommendations, having the same results as in the study of Kubicek et al. (2016).

In the past few years, the remuneration policy was debated by various researchers. For example, Kanapathippillai et al. (2015) studied the impact of remuneration committees and the voluntary disclosure of information on remuneration. By using the ordinary least squares (OLS) regression on a sample of the Top 200 Australian Securities Exchange (ASX) listed firms, the authors showed that the remuneration committees play an important role in the disclosure of information. Other authors such Porcuna Enguix (2021) analysed the new EU remuneration policy on bank executives' compensation incentives and the author examined the impact of the CSR initiative on bank CEO compensation. By collecting the data the EBA reports for the period 2010-2017 for the EU banking industry by focusing on the main bank material risk takers. The results of the study shows that the banks managers of the UK was the most acetated by the remuneration guidelines and the EU bank remuneration substantially favoured the fixed pay over the variable component.

Table 6. Remuneration Policy

\begin{tabular}{lcccccccc}
\hline $\begin{array}{l}\text { Recommendations } \\
\text { Countries }\end{array}$ & $\mathbf{1 9}$ & $\mathbf{2 0}$ & $\mathbf{2 1}$ & $\mathbf{2 2}$ & $\mathbf{2 3}$ & $\mathbf{2 4}$ & $\begin{array}{c}\text { No of } \\
\text { compliance }\end{array}$ & $\begin{array}{c}\text { \% of } \\
\text { compliance }\end{array}$ \\
\hline Bulgaria & Yes & Yes & Yes & Yes & No & No & 4 of 6 & $67 \%$ \\
Croatia & Yes & Yes & Yes & Yes & No & No & 4 of 6 & $67 \%$ \\
Czech Republic & No & Yes & Yes & Yes & No & No & 3 of 6 & $50 \%$ \\
Hungary & Yes & Yes & YES & Yes & Yes & No & 5 of 6 & $83 \%$ \\
Poland & Yes & No & No & No & No & No & 1 of 6 & $17 \%$ \\
Romania & No & No & Yes & Yes & No & No & 2 of 6 & $33 \%$ \\
Serbia & Yes & Yes & No & Yes & No & No & 3 of 6 & $50 \%$ \\
Slovakia & No & Yes & Yes & Yes & No & No & 3 of 6 & $50 \%$ \\
Slovenia & Yes & Yes & Yes & Yes & Yes & No & 5 of 6 & $83 \%$ \\
Ukraine & No & Yes & Yes & Yes & No & No & 3 of 6 & $50 \%$
\end{tabular}




\begin{tabular}{lcccccccc}
\hline $\begin{array}{l}\text { Recommendations } \\
\text { Countries }\end{array}$ & $\mathbf{1 9}$ & $\mathbf{2 0}$ & $\mathbf{2 1}$ & $\mathbf{2 2}$ & $\mathbf{2 3}$ & $\mathbf{2 4}$ & $\begin{array}{c}\text { No of } \\
\text { compliance }\end{array}$ & $\begin{array}{c}\text { \% of } \\
\text { compliance }\end{array}$ \\
\hline $\begin{array}{l}\text { Albania } \\
\text { Bosnia \& }\end{array}$ & Yes & No & Yes & No & No & No & 2 of 6 & $33 \%$ \\
Herzegovina & Yes & No & No & No & Yes & No & 2 of 6 & $33 \%$ \\
Estonia, & No & No & Yes & Yes & No & No & 2 of 6 & $33 \%$ \\
Latvia, & Yes & Yes & Yes & Yes & No & No & 4 of 6 & $67 \%$ \\
Lithuania, & Yes & Yes & Yes & Yes & Yes & No & 5 of 6 & $83 \%$ \\
Macedonia & No & No & No & Yes & No & No & 1 of 6 & $17 \%$ \\
Montenegro & Yes & Yes & No & No & No & No & 2 of 6 & $33 \%$ \\
Turkey & Yes & Yes & No & No & No & No & 2 of 6 & $33 \%$ \\
\hline $\begin{array}{c}\text { Codes including } \\
\text { recommendation }\end{array}$ & $\mathbf{1 2}$ & $\mathbf{1 2}$ & $\mathbf{1 2}$ & $\mathbf{1 3}$ & $\mathbf{4}$ & $\mathbf{0}$ & Average & $\mathbf{4 9 \%}$ \\
\hline
\end{tabular}

The results of our sample revels that almost $50 \%$ of the countries included in this study respect the recommendations issued by the European Commission regarding to the remuneration policy. On the previous study conducted by Kubicek et al. (2016) this percentage was higher, more than $70 \%$ respected the European Commission recommendations. Comparing with Kubicek et al. (2016) we observed that Poland, by updating its corporate governance code, introduced some aspects regarding remuneration policy, but not enough to be in line with the other countries. The last recommendation made by the European Commission regarding the share option included in the remuneration of non-executive or supervisory board is not respected by the countries included in our sample. Out of 18 countries included in our sample only Hungary, Slovenia, Bosnia \& Herzegovina and Lithuania respect the recommendation referring that shares should not vest for at least three years after their award.

Table 7. Role of Non-executive or Supervisory Directors of Listed Companies and on the Committees of the Board

\begin{tabular}{lcccccccccc}
\hline $\begin{array}{l}\text { Recommendations } \\
\text { Countries }\end{array}$ & $\mathbf{2 5}$ & $\mathbf{2 6}$ & $\mathbf{2 7}$ & $\mathbf{2 8}$ & $\mathbf{2 9}$ & $\mathbf{3 0}$ & $\mathbf{3 1}$ & $\mathbf{3 2}$ & $\begin{array}{c}\text { No of } \\
\text { compliance }\end{array}$ & $\begin{array}{c}\text { \% of } \\
\text { compliance }\end{array}$ \\
\hline Bulgaria & No & No & No & No & Yes & Yes & Yes & Yes & 4 of 8 & $50 \%$ \\
Croatia & Yes & Yes & Yes & No & Yes & Yes & Yes & Yes & 7 of 8 & $88 \%$ \\
Czech Republic & Yes & Yes & Yes & No & Yes & Yes & Yes & Yes & 7 of 8 & $88 \%$ \\
Hungary & Yes & Yes & Yes & No & Yes & Yes & Yes & Yes & 7 of 8 & $88 \%$ \\
Poland & No & Yes & No & No & No & Yes & No & No & 2 of 8 & $25 \%$ \\
Romania & Yes & Yes & Yes & No & Yes & Yes & Yes & Yes & 7 of 8 & $88 \%$ \\
Serbia & Yes & Yes & No & No & Yes & Yes & Yes & Yes & 6 of 8 & $75 \%$ \\
Slovakia & Yes & Yes & Yes & No & Yes & Yes & Yes & Yes & 7 of 8 & $88 \%$ \\
Slovenia & Yes & Yes & Yes & Yes & Yes & Yes & Yes & Yes & 8 of 8 & $100 \%$ \\
\hline
\end{tabular}


The compliance evolution of the corporate governance codes in emerging European countries - a content analysis perspective

\begin{tabular}{lcccccccccc}
\hline \begin{tabular}{l} 
Recommendations \\
\multicolumn{1}{c}{ Countries }
\end{tabular} & $\mathbf{2 5}$ & $\mathbf{2 6}$ & $\mathbf{2 7}$ & $\mathbf{2 8}$ & $\mathbf{2 9}$ & $\mathbf{3 0}$ & $\mathbf{3 1}$ & $\mathbf{3 2}$ & $\begin{array}{c}\text { No of } \\
\text { compliance }\end{array}$ & $\begin{array}{c}\text { \% of } \\
\text { compliance }\end{array}$ \\
\hline Ukraine & Yes & Yes & Yes & Yes & Yes & Yes & Yes & Yes & 8 of 8 & $100 \%$ \\
Albania & Yes & Yes & Yes & No & Yes & Yes & No & Yes & 6 of 8 & $75 \%$ \\
Bosnia \& & No & Yes & No & No & No & Yes & Yes & Yes & 4 of 8 & $50 \%$ \\
Herzegovina & No & Yes & No & No & No & Yes & Yes & Yes & 4 of 8 & $50 \%$ \\
Estonia & No & Yes & Yes & Yes & No & Yes & Yes & Yes & 6 of 8 & $75 \%$ \\
Latvia & Yes & Yes & Yes & No & Yes & Yes & Yes & Yes & 7 of 8 & $88 \%$ \\
Lithuania & Yes & No & No & No & Yes & Yes & No & Yes & 4 of 8 & $50 \%$ \\
Macedonia & Yes & Yes & Yes & No & Yes & Yes & Yes & Yes & 7 of 8 & $88 \%$ \\
Montenegro & No & Yes & Yes & No & No & Yes & No & Yes & 4 of 8 & $50 \%$ \\
Turkey & $\mathbf{1 2}$ & $\mathbf{1 6}$ & $\mathbf{1 2}$ & $\mathbf{3}$ & $\mathbf{1 3}$ & $\mathbf{1 8}$ & $\mathbf{1 4}$ & $\mathbf{1 7}$ & Average & $\mathbf{7 3 \%}$ \\
\hline $\begin{array}{l}\text { Codes including } \\
\text { recommendation }\end{array}$ & & & & & & & & &
\end{tabular}

The recommendation referring to the position of the non-executive and supervisory directors and the committees under the board issued by the European Commission were analysed in Table 7. By introducing this recommendation, the European Commission try to reduce the potential conflict of interest between the parties by dived the functions between non-executive and supervisory directors.

The recommendations issued by the European Commission were respected, in average, by $73 \%$ of the national corporate governance codes from our sample. Slovenia and Ukraine respect all the recommendations issued by the European Commission regarding these aspects meanwhile Poland respects only 2 out of the 8 recommendations from this list, being the country with least respected recommendations from our sample. The European Commission recommends that there should be at least one member with studies and experience in the remuneration field in the remuneration committee, but the results show that only Slovenia. Ukraine and Latvia respect this recommendation, being the least respected recommendation issued by the European Commission. It is important to notice that the recommendation referring that the board should make public at least once year information about its internal organisation and ensure that shareholders are properly informed as regards the affairs of the company, its strategic approach, and the management of risks and conflicts of interest is fulfil respected by all the countries and the recommendation referring to that the profile of non-executive or supervisory director in terms of their qualifications, commitment, and independence should be provided is respected by the all countries, except of Poland. 


\section{Conclusion}

This paper provides a general overview of the compliance of the corporate governance codes from eighteen Emerging European Countries with the European Commission recommendations issued in the period 2003-2009. Using the content analysis, this research presents which of the following recommendations issued by the European Commission regarding the enhancing corporate governance disclosure and institutional investors, strengthening shareholder's rights and modernising the board of directors, remuneration policy and the role of non-executive or supervisory directors of listed companies and on the committees of the board are respected by the following countries: Bulgaria, Croatia, Czech Republic, Hungary, Poland, Romania, Serbia, Slovakia, Slovenia Ukraine, Albania, Bosnia \& Herzegovina Estonia, Latvia, Lithuania, Macedonia Montenegro and Turkey.

The results illustrate that the countries included into the sample respect the recommendations issued by the European Commission. Referring to the corporate governance disclosure and institutional investors, the most respected recommendations is the recommendations regarding the shareholders meeting and its key power being respected by all the countries. With the except of Montenegro, the rest of the countries for our sample respect the recommendation (6) referring to the composition of the board and its committees. A disclosure of investment policy with respect to the exercise of voting rights in companies in which they invest is the less respected recommendation, Czech Republic, Serbia, Slovakia, Slovenia and Turkey are the countries present information in their codes.

In average, $57 \%$ of the countries respect the recommendations $10-18$, referring to the strengthening shareholder's rights and modernising the board of directors. Only the recommendation referring to the access the relevant information before the General Meetings (10) and disclosure of details of remuneration of individual directors (15) are respected by the all countries. Contrary the recommendation regarding to the cross-border voting (12) and the proper recognition in the annual accounts of the costs of such schemes for the company (17) are respected by Czech Republic, Hungary and Turkey.

The countries who respect more than $80 \%$ of the recommendations of European Commission regarding to the remuneration policy are Hungary and Slovenia, while Poland and Macedonia respects only 1 out of the 6 recommendations. Slovenia and Ukraine respect all the recommendation regarding the role of non-executive or supervisory directors of listed companies and on the committees of the board, while Poland respects only 2 out of the 8 recommendations.

Concerning to the countries who respect the recommendation of European Commission, Slovenia is the first with 28 recommendations respected out of 32 , 
followed by the Czech Republic with 27 recommendations respected and Slovakia with 26. The countries with least respected recommendations are Poland with 13 out of 32, Estonia with only 14 out of 32 recommendations and Bulgaria with 16 out of 32 recommendations. Our results for Poland are similarly with the results of Campbell et al. (2009) who studied the reasons of non-compliance of the Polish listed companies with the elements of corporate codes. The results of the study of Cicon et al. (2010) shows that Estonia has the lowest overall correlation with the UK code, which is one of the best codes. Also the in their report, The European Central Bank (2017) shows that Bulgaria needs some reforms of their corporate governance codes.

The limitation of this study is that it offer just a general overview regarding the compliance of corporate codes from European Emerging Countries with the European Commission recommendations, without practical implications. Future research directions may attempt to broaden the sample to all European countries who published a corporate governance code and finding new possible patterns of research in Europe. Moreover, future research could also investigate if the European Commission recommendations were implemented into the company's annual reports.

\section{Acknowledgements}

We appreciate the helpful comments and the constructive suggestions on previous draft of this study presented at the International Conference Accounting and Management Information Systems (AMIS 2021), Bucharest, Romania. Special thanks are addressed to the anonymous reviewers of this research for their insightful recommendations.

\section{References}

Aguilera, R.V. \& Cuervo-Cazurra, A. (2004) "Codes of good governance worldwide: what is the trigger?" Organization Studies, vol. 25, no. 3: 415-443

Albu, C. N. \& Girbina, M. M. (2015) "Compliance with corporate governance codes in emerging economies. How do Romanian listed companies "comply-orexplain"?", Corporate Governance: The International Journal of Business in Society, vol. 15, no 1: 85-107

Allen, F. (2005) "Corporate governance in emerging economies", Oxford Review of Economic Policy, vol. 21, no. 2: 164-177

Al-Malkawi, H.A.N., Pillai, R. \& Bhatti, M.I. (2014) "Corporate governance practices in emerging markets: The case of GCC countries", Economic Modelling, vol. 38:133-141 
Ararat, M., Claessens, S. \& Yurtoglu, B.B. (2020) "Corporate governance in emerging markets: A selective review and an agenda for future research", Emerging Markets Review, in press

Boitan, I. A., \& Maruszewska E. W. (2021) "Corporate governance features among European Union countries - an exploratory analysis" The Review of Finance and Banking, vol. 13-1: 79-91

Bosakova, I., Kubicek, A. \& Strouhal, J. (2019) "Governance codes in the developing and emerging countries: Do they look for the international role model?", Economics and Sociology, vol. 12, no. 3: 251-272

Bosáková, I., Kubíček, A., \& Strouhal, J. (2019) "Governance codes in the developing and emerging countries: Do they look for the international role model?", Economics and Sociology, vol. 12, no. 3: 251-272

Campbell, K., Jerzemowska, M., \& Najman, K. (2009) "Corporate governance challenges in Poland: evidence from "comply or explain" disclosures", Corporate Governance: The International Journal of Business in Society, vol. 9, no. 5: 623-634.

Cicon, J. E., Ferris, S. P., Kammel, A. J., \& Noronha, G. (2010). "European Corporate Governance: a thematic analysis of national codes of governance", European Financial Management, vol. 18, no. 4: 620-648

Claessens, S., \& Yurtoglu, B. B. (2013) „Corporate governance in emerging markets: A survey", Emerging Markets Review, vol. 15: 1-33

Commission Recommendation of 14 December 2004 fostering an appropriate regime for the remuneration of directors of listed companies Text with EEA relevance https://eur-lex.europa.eu/legal-content/EN/TXT/?uri=CELEX\% 3A32004H0913

Commission Recommendation of 15 February 2005 on the role of non-executive or supervisory directors of listed companies and on the committees of the (supervisory) board (Text with EEA relevance), https://eurlex.europa.eu/legal-content/EN/ALL/?uri=CELEX\%3A32005H0162

Commission Recommendation of 30 April 2009 on remuneration policies in the financial services sector (Text with EEA relevance), https://eurlex.europa.eu/legal-content/EN/TXT/?uri=CELEX\%3A32009H0384

Communication from the Commission to the Council and the European Parliament - Modernising Company Law and Enhancing Corporate Governance in the European Union - A Plan to Move Forward, https://eur-lex.europa.eu/legalcontent/EN/ALL/?uri=celex\%3A52003DC0284

Corporate Governance Sector Assessment, Bulgaria case, https://www.ebrd.com/ what-we-do/sectors/legal-reform/corporate-governance/sectorassessment.html, consulted on July 2021

Cuomo, F., Mallin, C., Zattoni, A. (2015), "Corporate Governance Codes: A Review and Research Agenda", Corporate Governance: An International Review, vol. 24, no. 3: $222-241$

ECGI webpage, https://ecgi.global/content/codes, consulted on July 2021 
Esqueda, O. A. \& O'Connor, T. (2020) "Corporate governance and life cycles in emerging markets" Research in International Business and Finance, 101077.

Feng, M., Kang, T., \& Nabar, S. (2017) "National societal values and corporate governance", International Journal of Emerging Markets, vol. 12, no. 2: 183-198

Ferdous, C. S., Mallin, C., \& Ow-Yong, K. (2014) „Corporate Governance in Bangladesh: A comparison with other emerging market countries", Corporate Governance in Emerging Markets, 395-420

Hermes, N., Postma, T. J. B. M., \& Zivkov, O. (2006) "Corporate governance codes in the European Union", International Journal of Managerial Finance, vol. 2, no. 4: 280-301.

Hermes, N., Postma, T. J., Zivkov, O. (2007) "Corporate governance codes and their contents-An analysis of Eastern European codes", Journal for East European Management Studies, vol. 12, no. 1: 53-74

Hugill, A. \& Siegel, J. I. (2012) "Which does more to determine the quality of corporate governance in emerging economies, firms or countries?" SSRN Electronic Journal, doi:10.2139/ssrn.2192460

Kanapathippillai, S. \& Johl, S.K. \& Wines, G. (2015) "Remuneration committee effectiveness and narrative remuneration disclosure", Pacific-Basin Finance Journal, Elsevier, vol. 40: 384-402.

Kubicek, A., Stamfestova, P. \& Strouhal, J. (2016) "Cross-Country Analysis of Corporate Governance Codes in the European Union", Economics and Sociology, vol. 9, no 2: 319-337

Owusu, A. (2016). "What drives corporate governance quality in emerging african economies? Evidence from Ghana", The Journal of Developing Areas, vol. 50, no. 4: 97-111

Peters, S., Miller, M., \& Kusyk, S. (2011) "How relevant is corporate governance and corporate social responsibility in emerging markets?", Corporate Governance: The International Journal of Business in Society, vol. 11, no. 4: 429-445

Porcuna Enguix, L. (2021) "The New EU Remuneration policy as good but not desired corporate governance mechanism and the role of CSR disclosing", Sustainability, vol 13: 5476

Sahin, K. (2014), "The legitimacy of codes of corporate governance: perspectives from developed and emerging economies", Journal of Management \& Governance, vol. 19, no. 3: 687-708

Shala, A. \& Qehajat, B. (2021) "The practices and corporate governance frameworks: comparative evidence from South-Eastern European countries", Eastern Journal of European Studies, Vol. 12-1: 53-80

Siddiqui, J. (2009) „Development of Corporate Governance Regulations: The Case of an Emerging Economy", Journal of Business Ethics, vol. 91: 253-274, Available at SSRN: https://ssrn.com/abstract=1374371 
Soppa K. \& Baumüller, J. (2012) "Remuneration systems of the management board and corporate governance reporting - Evidence from Austria", Procedia Economics and Finance, vol. 2: 35-44

Tsamenyi, M., \& Uddin, S. (2008) "Introduction to corporate governance in less developed and emerging economies", Corporate Governance in Less Developed and Emerging Economies, 1-11

Yusof N.Z.M. (2016) "Context matters: a critique of agency theory in corporate governance research in emerging countries", International Journal of Economics and Financial Issues, vol. 6, no. 7: 154-158 